\title{
THE JUDICIARY AS AN INSTITUTION
}

\author{
Sir Geoffrey Palmer $Q C^{*}$
}

This issue of the Victoria University of Wellington Law Review contains a symposium of student work on the judiciary. This introductory article sets out the circumstances surrounding the preparation of the articles and the course of instruction that preceded them. It also sets out the constitutional background relating to the New Zealand judiciary and introduces the articles themselves. It refers to some changes contained in the Judicature Modernisation Bill that was nearing the end of its parliamentary passage when editing of the symposium was completed.

\section{THE CONSTITUTIONAL CONTEXT}

The New Zealand judiciary is an under-studied institution. Many of its features are so familiar that they are never questioned. Yet the way judges are recruited, appointed, the mechanisms for complaining about them, the conventions under which they work, the grounds for their removal and the constitutional principle of their independence from the other branches of government, are all matters of great public moment for a democracy based on the rule of law. We have many more judges in New Zealand than members of Parliament but they are less researched. The decisions of judges are the subject of scholarly analysis but not so much the institution of the judiciary. The public power with which judges are entrusted to exercise and adjudicate over the rights and obligations individual citizens is considerable.

Part 4 of the Constitution Act 1986 contains two important provisions relating to the judiciary, both of them deriving from constitutional developments long ago. Section 23 protects judges against removal from office:

... except by the Sovereign or the Governor-General, acting upon an address of the House of

Representatives, which address may be moved only on the grounds of that Judge's misbehaviour or of that

Judge's incapacity to discharge the functions of that Judge's office.

This provision has its origins in the English Act of Settlement 1701 that is regarded as establishing the principle that judges were subject to direction neither from the monarch, nor Parliament nor ministers.

* Distinguished Fellow, Victoria University of Wellington, Faculty of Law and Centre for Public Law. 
Section 24 provides that the salary of a judge of the High Court shall not be reduced during the continuance of the judge's commission. Both these provisions have been part of New Zealand law from relatively early days. ${ }^{1}$ It is noteworthy that District Court judges do not enjoy the same degree of protection from dismissal as High Court judges and in the writer's opinion the level of protection should be the same. The Governor-General can remove the District Court judges on ministerial advice, for "inability or misbehavior". 2

The Constitution Act does not tell the whole story. There are constitutional conventions surrounding the judiciary, as there are for other features of New Zealand government, particularly Cabinet. For example, the Cabinet Manual restricts public comment by ministers on judicial decisions that could be understood "as reflecting adversely on the impartiality, personal views, or ability of any Judge". 3

As to the removal and discipline of judges, a statute now provides that complaints may be made about the conduct of judges in exercise of their judicial functions: the Judicial Conduct Commissioner and Judicial Conduct Panel Act 2004. ${ }^{4}$ If an address of the House of Representatives is to be moved to remove a Judge first there will be an investigation under the Act and a decision to set up a Judicial Conduct Panel. One of the statutory functions of the Commissioner in appropriate cases is to recommend that a Judicial Conduct Panel be appointed to inquire into any matter or matters concerning the conduct of a Judge. ${ }^{5}$ The power set out in s 18 provides:

(1) The Commissioner may recommend to the Attorney-General that he or she appoint a Judicial Conduct Panel to inquire into any matter or matters concerning the alleged conduct of a Judge if the Commissioner is of the opinion that-

(a) an inquiry into the alleged conduct is necessary or justified; and

(b) if established, the conduct may warrant consideration of removal of the Judge.

1 Judicature Act 1908; Supreme Court Act 1882; Supreme Court Judges Act 1858; and Constitution Act 1852 (UK), s 65. The Imperial Laws Application Act 1988 affirms some of the provisions of the Act of Settlement 1701. For a discussion of the issues relating to judicial selection and accountability, see Geoffrey Palmer "Judicial Selection and Accountability: Can the New Zealand System Survive?" in BD Gray and RB McClintock Courts and Policy-Checking the Balance (Brookers, Wellington, 1995) 11; Philip A Joseph "Appointment, discipline and removal of judges in New Zealand" in HP Lee (ed) Judiciaries in Comparative Perspective (Cambridge University Press, Cambridge, 2011) 66; Philip A Joseph Constitutional and Administrative Law in New Zealand (4th ed, Thomson Reuters, Wellington, 2014), ch 21.

2 District Courts Act 1947, s 7

3 Cabinet Office Cabinet Manual 2008 at [4.12]-[4.15].

4 For an account of the writer's involvement in writing a report that led to this statute, see Geoffrey Palmer Reform: A Memoir (Victoria University Press, Wellington, 2013) at 303-308.

5 Judicial Conduct Commissioner and Judicial Conduct Panel Act 2004, s 8. 
(2) The Commissioner must give reasons with his or her recommendation under subsection (1).

(3) The Commissioner must give the complainant and the Judge who is the subject of the complaint written notification of any action taken under subsection (1).

While no judge in the history of New Zealand has been removed by an address of the House of Representatives, a Judicial Conduct Panel was set up in 2010 to inquire into the conduct of Wilson J who was by then a Supreme Court Judge having been first directly appointed to the Court of Appeal. The complicated judicial proceedings preceding and following this decision cannot be reviewed here, and they are highly involved and contested. ${ }^{6}$ The developments, after judicial review by a Full Court of the High Court reviewing the decisions of the Commissioner, resulted in Wilson $\mathrm{J}$ resigning his office.

The unfortunate saga surrounding Wilson J's resignation caused significant professional disquiet amongst lawyers and judges in New Zealand. The last word on it has yet to be written. The Wilson affair itself is not directly analysed in these articles but it weighed upon the minds of students. In the public mind, the events shone a light upon the judiciary in an area that had seldom come to public attention. One article attempts to look at the situation now the dust has settled and explore a practical process and procedural reform for recusal that could improve the present situation.

The events sharpened and brought into focus the New Zealand law and procedure concerning recusal and bias. The dispute arose a case in the Court of Appeal in which Wilson J, then a Judge of that Court, was on the bench and appearing before him was Alan Galbraith QC. Wilson J had telephoned the barrister representing the other side to disclose that he and Mr Galbraith had some mutual business association that was not described. New evidence came to light of the business association and the Supreme Court having dismissed the appeal from the Court of Appeal later granted a new application since the Judge and counsel were sole partners and shareholder in a horse stud. It was a significant business. ${ }^{7}$

The articles written by the students demonstrate that there are many aspects of the judiciary that can benefit from further research and study. The course took place while the Judicature Modernisation Bill was under active consideration by the House of Representatives. The constitutional fundamentals

6 Gerard McCoy "Judicial recusal in New Zealand" in HP Lee (ed) Judiciaries in Comparative Perspective (Cambridge University Press, Cambridge, 2011) 322. The key decisions are: Saxmere Co Ltd v Wool Board Disestablishment Co Ltd [2007] NZSC 88; Saxmere Co Ltd v Wool Board Disestablishment Co Ltd [2008] NZSC 94, (2008) 19 PRNZ 132; Saxmere Co Ltd v Wool Board Disestablishment Co Ltd [2009] NZSC 72, [2010] 1 NZLR 35; Saxmere Co Ltd v Wool Board Disestablishment Co Ltd (No 2) [2009] NZSC 122, [2010] 1 NZLR 76; Wilson v Attorney-General (Judicial Conduct) [2010] NZAR 434 (HC); Wilson v AttorneyGeneral (Judicial Conduct) (No 2) [2010] NZAR 509 (HC); and Wilson v Attorney-General [2011] 1 NZLR 399 (HC).

7 There is an interesting synopsis of the events surrounding this matter and media commentary on it in Mai Chen Public Law Toolbox (2nd ed, LexisNexis, Wellington, 2014) at 906-910. 
are one thing. The reality of how the institution works in the political framework of New Zealand's constitution and government is another.

The Judicature Modernisation Bill, that had been in the law-making system for a long time, was reaching its final legislative stages at the time of writing. It has important features relating to appointment and qualifications of judges that were the subject of a Law Commission report that has not been followed in important respects. ${ }^{8}$ Clause 94 largely preserves the historic position that to be a judge a person has "for at least 7 years, held a New Zealand practising certificate as a barrister or as a barrister and solicitor" but with the added feature that a New Zealand law graduate who has practised overseas in an approved jurisdiction can in some circumstances be appointed. Clause 93 requires the Attorney-General to publish information explaining his or her process for seeking expressions of interest in judicial appointment and for recommending persons for appointment. The New Zealand Law Society, in this regard, submitted to the Select Committee scrutinising the Bill as follows: ${ }^{9}$

There are few formal checks and balances in New Zealand upon the Executive's power to appoint judges. The independence of the judiciary and the rule of law would both benefit from greater specificity about what the criteria for appointment are and the identity of those who must be consulted. Matters of such constitutional importance should be contained in statute law.

As the Law Commission has said, the criteria for appointment are doubtless already applied, but it would engender public confidence and transparency to state them explicitly. Similarly, the Law Commission encountered little controversy when it came to the list of people who should be consulted. The Law Society is not aware of any reason why these recommendations should not be adopted.

The Law Commission made the following recommendations on the people to be consulted and additional statutory criteria for appointment of judges, and with whom the Attorney-General should be required to consult before making recommendations: ${ }^{10}$

R16 There should be additional statutory criteria for appointment as a judge as follows:

(a) the person to be appointed a judge must be selected by the Attorney-General on merit, having regard to that person's -

- $\quad$ personal qualities (including integrity, sound judgment, and objectivity);

- legal abilities (including relevant expertise and experience and appropriate knowledge of the law and its underlying principles);

8 Law Commission Review of the Judicature Act 1908: Towards a New Courts Act (NZLC R126, 2012).

9 New Zealand Law Society "Submission to the Justice and Electoral Committee on the Judicature Modernisation Bill 2013" at [44] and [45].

10 Law Commission, above n 8, at R16 and R17. 
- $\quad$ social awareness of and sensitivities to tikanga Māori; and

- $\quad$ social awareness of and sensitivities to the other diverse communities in New Zealand; and

(b) regard must be given to the desirability of the judiciary reflecting gender, cultural and ethnic diversity.

R17 Before making an appointment, whether "first instance" or an elevation to a higher court, the Attorney-General should be required by statute to consult:

- the Chief Justice, in the case of an appointment to the Higher Courts, and the Chief District Court Judge, in the case of appointment to the District Courts;

- $\quad$ the Head of Bench of the court to which the appointment will be made;

- $\quad$ the Solicitor-General;

- $\quad$ the President of the New Zealand Law Society;

- $\quad$ the President of the New Zealand Bar Association; and

- $\quad$ such other persons as he or she considers to be appropriate.

No change was made to the Bill as a result of this submission by the Law Society. It will be a live issue in the years to come whether the traditional lack of transparency in judicial appointments can survive in an age increasingly sceptical about the use of public power.

Another constitutional point should be noted. The doctrine of parliamentary sovereignty that holds sway in New Zealand has received statutory recognition in the Supreme Court Act 2003. Section 3(2), the Act's purpose provision, provides: "Nothing in this Act affects New Zealand's continuing commitment to the rule of law and the sovereignty of Parliament." The Judicature Modernisation Bill that, when enacted will produce a new Senior Courts Act, fails to repeat these provisions. The loss of the rule of law provision was the subject of critical comments from McGrath $\mathrm{J}$ in his remarks delivered on the occasion of his final sitting in the Supreme Court on 6 March 2015. It is also possible that something has been lost in the consolidation because of the failure to repeat s 3(1)(a)(ii): "to enable important legal matters relating to the Treaty of Waitangi, to be resolved with an understanding of New Zealand conditions, history, and traditions".

\section{THE STUDENT ARTICLES}

The articles published in this issue are revised research papers students wrote for a course taught by me in 2014. I offered a full year course for LLB(Hons) and LLM students on the judiciary. The final product for each student was a 15,000-word research paper. The seven students who took this class had diverse legal interests and backgrounds. They chose their own research topics and reached their own conclusions. I gave them criticism and help, but the views put forward are their own. 
What does strike me about these articles is how well researched they are and how mature are the views expressed. Some of them are constructively critical, others make important suggestions for new policies in relation to the topics with which they deal. One enduring theme in many of the articles is the demand for factual empirical research being done and considered before big innovations within the judicial system are considered. It seems that the new generation of lawyers will not favour seatof-the pants research as a basis for policy as some practitioners did in days gone by. Indeed, some of the students engaged in empirical research and present the results in their articles.

In order to prepare their research the course provided important instruction in several matters. The students had all done the basic law courses and were familiar with the central principles of the independence of the judiciary, the role of the courts in resolving disputes and qualifications for being appointed a judge.

In order to delve into some of the issues in greater depth we did two things. First, we discussed some readings, and secondly heard at length from two judges.

Readings from a recent book, Judiciaries in Comparative Perspective edited by Professor HP Lee of Monash University, were discussed. ${ }^{11}$ This book provides a set of perspectives from principally common law countries: the United Kingdom; Australia; Canada; New Zealand; the United States; and South Africa. The contributors came from the countries about which they wrote. The topics covered appointment, discipline and removal of judges; judges' freedom of speech; judicial bias and recusal; and non-judicial functions of judges.

Secondly, we had two long sessions with Judges - Justice John McGrath of the New Zealand Supreme Court and Judge Thomas Broadmore of the District Court - both of whom gave up a Saturday morning each for this purpose. For the students, hearing from the Judges about how they see their work provided a convenient bridge between theory and practice. These were sessions rich in insight and gave the students an appreciation of the range of judicial work that exists in New Zealand. In the case of Justice McGrath, who had occupied the office of Solicitor-General, he was also able to discuss the unique character of that office. In the case of Judge Broadmore, a leading authority on the law of admiralty, students were able to understand the complex professional backgrounds of members of the judiciary.

Students presented two seminar papers each, in addition to writing their research papers. But the seminar papers were organised in such a way as to ensure they contributed a context to the research paper on the student's chosen topic. The topics for the research papers moved around a bit as students' research deepened and the problems of scope became more apparent.

The class was fortunate in having as one of its members a Swiss post-graduate student, Benjamin Suter, whose article appears first in the symposium. He provides a comparative perspective that

11 HP Lee (ed) Judiciaries in Comparative Perspective (Cambridge University Press, Cambridge, 2011). 
stretched both the minds and the cultural assumptions of the New Zealand students and indeed their instructor.

In Switzerland, judges are elected and they must face re-election. Legal qualifications are not essential. Judges must be members of a political party and judges reflect the range of political opinion in the society. Judges are required to surrender a portion of their judicial salary to their political party. The Swiss argument is that having a diversity of political views in the courts is beneficial in ensuring that justice is seen to be done. The Swiss judiciary has no place for politically neutral people. How could such a judiciary be independent in the sense that common lawyers understand that term, the New Zealanders asked in the course of the class. The answer is that Switzerland is a highly successful country by almost any measure that can be brought to bear upon the question. The performance of the judiciary does not reflect the infirmities that the institutional arrangement may suggest to the common law mind. The stability of Switzerland is remarkable. For more than 50 years the Swiss Federation has been governed by a loose coalition of the same four largest political parties.

So the learning must be that there is more than one way to organise the judiciary and it cannot be assumed that the New Zealand way is the only one that can be successful. Political culture develops slowly over time and the Swiss seem to be able to handle fairly easily issues that we may think would fatally impair the independence of the judiciary. Mr Suter's article sets out the elements of the Swiss system in a most interesting way by comparing it with New Zealand, and it serves to encourage us to keep open minds on issues that many consider to have been settled long ago.

Judicial specialisation has been a live topic in New Zealand for some years. There have been calls from the legal profession for specialised commercial courts and specialised tax courts. Two of the articles in the symposium deal with these subjects at length. Both articles conclude upon analysis that substantial difficulties exist in a small jurisdiction like ours to successfully implement such a programme. These conclusions may not be welcomed by people in the profession who have vigorously championed specialisation. The policy point is that the case for change needs to be developed much more systematically before it can be supported. The research and analysis presented in these two articles and the arguments have power and need to be seriously considered.

William Steel's article focuses on whether commercial specialisation within the High Court is justified. Following a series of Law Commission reports and years of discussion, cl 18 of the Judicature Modernisation Bill was still in front of Parliament at the time of writing. ${ }^{12}$ It provides for a commercial panel of the High Court and indeed panels in other legal areas in the fullness of time. The Bill has been reported back by from the Select Committee with slight changes. The intent is to replace the present commercial list. The author subjects this proposal to remorseless criticism: the case of specialisation has not been made out; there is no empirical evidence to support the claim that the High Court is suffering from a falloff in the commercial work; and there are serious constitutional

12 Judicature Modernisation Bill 2013 (178-2). 
issues involving the independence of the judiciary residing in what is proposed. The proposal places too much power in the hands of the Chief High Court Judge and threatens to undermine the principle of judicial independence. This is an ambitious claim, but the detailed argumentation to support it is well marshalled.

Sarah Miles' article, by way of contrast, deals with specialisation in tax law, another area where there have been professional calls for change. New Zealand already has a Taxation Review Authority staffed by a District Court Judge. So already there is a degree of specialisation built into the system, although for reasons discussed in the article the quantity of work for the Taxation Review Authority has fallen off in recent years. No arrangements exist at present for specialisation at the High Court level. The arrangements for specialisation in other jurisdictions are examined. But Sarah Miles argues that while it may have been successful overseas, further specialisation will not necessarily be successful here. Indeed, she arrives at the conclusion that the size of New Zealand and other factors militate against it.

The article by Chamika Gajanayaka sets out to find a practical way through the complications of the New Zealand law on judicial recusal. He found a mismatch between process theory and the haphazard self-regulation that occurs. His is an attempt to bring recusal procedure into line with general civil litigation.

He posits the case that had his suggested reform been in use at the time events relating to Wilson $\mathrm{J}$ took place, the controversy could have been mitigated, if not avoided. He examines cognitive research mainly from the United States. He argues that reform should come from within the judiciary, not from outside it. His answer is that all recusal motions should be heard by an independent judge. The issue is whether in light of the experience of the events surrounding Wilson J, a new procedure should be adopted. The essence of proposal is that a sitting judge should not decide on a recusal motion relating to him or her. This position is advanced in order to engender public confidence in the judiciary, a quintessential necessity for the institution. This article was informed by the work of by Sir Grant Hammond in his 2009 book. $^{13}$

Jasmin Moran tackles another element of judicial behaviour: the extent to which judges have a right to free speech off the bench. This issue also bears upon recusal in some cases. Here the issue is: What effect can extrajudicial speeches and articles have on a judge's impartiality? The thesis advanced by two Australian academics, Susan Bartie and John Gava, in the Sydney Law Review is that the answer lies in judicial silence off the bench. ${ }^{14}$ This extreme position finds no favour with the author. Once it is accepted that not every piece of judicial writing on a live issue results in prejudgment, complete silence is an overreaction. Jasmin Moran has engaged in a helpful piece of empirical research to discover the extent of extrajudicial writing in New Zealand. Her research presented in the

13 Grant Hammond Judicial Recusal: Principles, Process and Problems (Hart Publishing, Oxford, 2009).

14 Susan Bartie and John Gava "Some Problems with Extrajudicial Writing" (2012) 34 Syd L Rev 637. 
article shows two most prolific authors turn out to be Elias CJ and Judge Boshier. She argues, quite correctly in my view, that to insist upon the degree of extrajudicial silence advocated by the two Australians in New Zealand would be unnecessary and "defies common sense".

The article by Juliet Bull asks the constitutional question: If New Zealand had an entrenched Bill of Rights Act that is supreme law would the process for judicial appointments in New Zealand have to change? Her answer is yes. The reasoning lies in the Canadian experience with judicial appointments following adoption of the Charter of Rights and Freedoms. ${ }^{15}$ Canada has a supreme law Charter of Rights and Freedoms, and in the formation of the New Zealand Bill of Rights Act 1990 the Canadian drafting and experience was relied upon quite heavily. Ms Bull's research on this question brings to the fore an unsatisfactory situation that could well occur in New Zealand unless remedial steps were taken. The difficulty lies in deciding upon what those steps should be. The threat comes of the risk of judicial appointments becoming politicised. The evidence shows the difficulties in Canada are substantial and have yet to be satisfactorily resolved. The article considers a number of possible solutions and comes down in favour of the creation of a Judicial Appointments Commission. Building on the Ministry of Justice's 2004 consultation paper, the author argues for a Commission with a membership along the following lines:

- $\quad$ the Chief Justice;

- the Chief Judge of the court in which the vacancy occurs;

- the President of the New Zealand Law Society;

- the President of the New Zealand Bar Association;

- the Solicitor-General; and

- two members of Parliament.

All the members of the Commission would be defined by the offices they occupy. There would be no need for government appointments. The Commission would present the Attorney-General with a list of three names from which he would select one to recommend to the Governor-General.

The final article in the symposium deals with the vexed issue of judicial sentencing for crime. Sean J Mallett argues that the criminal law requires consistency in sentencing - like offenders must be treated alike. But empirical research in New Zealand that the article cites demonstrates that consistency is not achieved. The empirical evidence presented in the article on the disparity in sentencing is of serious concern. To remedy the problem, principles laid out in statutory directions to judges and guideline judgments from the courts are both found to be inadequate. A remedy of mandatory sentencing replacing judicial discretion is not favoured by the author, for a number of reasons that are advanced. The approach of statutory presumptions is examined and rejected. But an "instinctive synthesis" approach by judges in which there are no rules is not favoured either. Sean

15 Canadian Charter of Rights and Freedoms, Part 1 of the Constitution Act 1982, being sch B to the Canada Act $1982(\mathrm{UK})$. 
Mallett then examines the New Zealand Sentencing Council proposal that followed a Law Commission report ${ }^{16}$ and was enacted in the Sentencing Council Act 2007. The statute has never been brought into force after the government changed in 2008. He concludes that the implementation of the Sentencing Council Act with a mandate to draft guidelines is the best way forward for New Zealand's criminal justice system. He raises the lingering constitutional issue of leaving a statute passed by Parliament on the statute book but not implementing it.

\section{CONCLUSION}

In this symposium, an intellectually talented group of young New Zealanders and a Swiss have engaged with some deep issues concerning the New Zealand judiciary. They have done so with extensive, even exhaustive, research. They write clearly and well. They have something to say that is worth listening to. It was a pleasure to teach them and I learned a lot from them. Six of them will go on to make their mark upon New Zealand law. I encouraged them at the beginning by saying if the work was good enough I would advocate its publication. I am delighted they met the challenge and the University responded.

Dr Matthew Palmer QC has expressed the view the judiciary is the bulwark for the rule of law in this country, as the primary external and independent check against the abuse of power by the political branches of government. He says: $:^{17}$

New Zealanders usually appear to accept and respect Judges and courts as a necessary and desirable part

of our system of government. But I have a normative concern about how deeply that acceptance is rooted

in our constitutional culture.

Hopefully studies like those contained in this symposium will lift the level of civic virtue, and enhance interest in and knowledge about the judiciary.

The history of the Victoria University of Wellington shows that the Victoria University of Wellington Law Review began in 1953 and was established "as a forum for student writing". ${ }^{18}$ I am delighted that this symposium satisfies that historic and noble purpose.

16 Law Commission Sentencing Guidelines and Parole Reform (NZLC R94, 2006).

17 Matthew Palmer "The Place of the Judiciary in the Constitutional Culture of New Zealand (paper presented to the Symposium on Australian Constitutionalism, Melbourne, December 2013).

18 Rachel Barrowman Victoria University of Wellington 1899-1999: A History (Victoria University Press, Wellington, 1999) at 232. 